\title{
Proteomic Profiling of a Snake Venom Using High Mass Detection MALDI-TOF Mass Spectrometry
}

\author{
Oscar Yanes* ${ }^{+}$and Francesc X. Avilés \\ Institut de Biotecnologia i Biomedicina and Departament de Bioquimica i Biol. Mol., Universitat Autònoma \\ de Barcelona, Bellaterra (Barcelona), Spain
}

\author{
Ryan Wenzel, ${ }^{+}$Alexis Nazabal, ${ }^{+}$and Renato Zenobi \\ Department of Chemistry and Applied Biosciences, Swiss Federal Institute of Technology (ETH), Zürich, \\ Switzerland
}

\author{
Juan J. Calvete \\ Instituto de Biomedicina de Valencia, C.S.I.C, Valencia, Spain
}

Proteomic profiling involves identification and quantification of protein components in complex biological systems. Most of the mass profiling studies performed with matrix-assisted laser desorption/ionization time-of-flight mass spectrometry (MALDI-TOF MS) have been restricted to peptides and small proteins $(<20 \mathrm{kDa})$ because the sensitivity of the standard ion detectors decreases with increasing ion mass. Here we perform a protein profiling study of the snake venom Sistrurus miliarius barbouri, comparing 2D gel electrophoresis and reversed-phase high-performance liquid chromatography (HPLC) with a high mass cryodetector MALDI-TOF instrument (Macromizer), whose detector displays an uniform sensitivity with mass. Our results show that such MS approach can render superior analysis of protein complexity compared with that obtained with the electrophoretic and chromatographic approaches. The summation of ion impacts allows relative quantification of different proteins, and the number of ion counts correlates with the peak areas in the reversed-phase HPLC. Furthermore, the sensitivity reached with the high mass cryodetection MS technology clearly exceeds the detection limit of standard high-sensitivity staining methods. (J Am Soc Mass Spectrom 2007, 18, 600-606) (c) 2007 American Society for Mass Spectrometry

$\mathrm{P}$ rotein profiling has become a powerful method for analyzing changes in global protein expression patterns in biological systems as a function of developmental, physiological, and disease processes. Two-dimensional (2D) gel electrophoresis has been established for many years as the primary tool for detecting proteins present in an organism or a complex biological extract. However, 2D gel electrophoresis has some limitations: limited solubility of hydrophobic and membrane proteins, limited dynamic range, difficulty in focusing highly basic and acidic proteins, poor sensitivity, poor quantitation, and finally, the method is not amenable to automation. The limitations associated with gel electrophoretic analysis of peptides

Published online January 3, 2007

Address reprint requests to Dr. F. X. Avilés, Institut de Biotecnologia i Biomedicina and Departament de Bioquímica i Biol. Mol., Universitat Autònoma de Barcelona, 08193 Bellaterra (Barcelona), Spain. E-mail: Francesc.Xavier.Aviles@uab.es

* Also at the Department of Chemistry and Applied Biosciences, Swiss Federal Institute of Technology (ETH), Zürich, Switzerland.

+ CovalX GmbH, Schumacherweg 15, CH-8046, Zürich, Switzerland. and small proteins $(<20 \mathrm{kD})$ have stimulated interest in mass spectrometry as an alternative strategy. In this sense, MALDI-TOF mass spectrometry has partially replaced or complemented gel-based approaches for studying the proteomic profile of the low mass components of many complex biological samples such as serum [1] or tissues [2]. Imaging MS [2] and chip-based technologies such as surfaceenhanced laser desorption/ionization (SELDI-MS) [3] are relatively new approaches that take advantage of the established features of MALDI MS (mass accuracy, sensitivity, reliability, and high-throughput) to detect and identify peptides and proteins. Also, 1D and 2D liquid chromatography coupled to detection systems such as UV and/or MALDI, have been gradually introduced for the analysis and profiling of intact (top down proteomics) $[4,5]$ and digested proteins (bottom up proteomics) [6] in complex biological mixtures. MALDI is a soft ionization method and produces predominantly singly charged molecular ions regardless of the molecular weight. Hence, the spectra are relatively easy to interpret. 
Up to now, most of the profiling studies carried out using MALDI-TOF mass spectrometry have been performed using instruments with standard ion detectors, such as microchannel plates (MCP), which work by ion-to-electron conversion following the impact of high velocity ions on the detector surface, initiating an electron cascade. However, the conversion efficiency is extremely low for large, low velocity ions, and an exponential decrease in efficiency can be readily observedí atí higherí massesí [7,í 8].í Additionally,í MCP channels have a very slow refresh time, about several milliseconds. This means that when an ion impacts a channel, it is turned off for the duration of the analysis (microseconds). When measuring complex samples that contain ions over a broad mass range, the lower intensity ions will saturate some channels of the detector, preventing the analysis of the higher ions, again leading toíaídecreaseíinísensitivityíforílargerímassíionsí[9].íAs an alternative, cryodetection is an ion detection method that does not suffer from a decrease in sensitivity for high $\mathrm{m} / \mathrm{z}$ ions or from a decrease in sensitivity from complexísamplesí[10,í11].íTheícapacityíofítheí cryodetectorítechnologyí[12],íorírecentlyíproposedíequivalent substitutesí [13]í forí intactí proteiní analysisí ofí highly complex protein mixtures, with uniform sensitivity, independent of mass, provides a new opportunity to establish MALDI mass spectrometry in the field of protein profiling for all mass ranges.

In the present work, we demonstrate the protein profiling of crude snake venom from Sistrurus miliarius barbouri using cryodetection MALDI TOF mass spectrometry. The results were compared with those obtainedíbyíJuarezíetíal.í[14]íusingí2Dígelíelectrophoresis and reversed-phase HPLC liquid chromatography (LC), highlighting the sensitivity of cryodetection and its ability for relative quantification of different analytes in the same spectrum. Overall, we demonstrate the power of this new technology to be implemented as a mass spectrometrybased quantitative proteomic profiling strategy.

\section{Experimental}

\section{Cryodetection MALDI-TOF MS}

A linear MALDI-TOF mass spectrometer equipped with a cryogenic superconducting tunnel junction array detector (VTT Technical Research Center of Finland, Espoo, Finland) was used for this study (Macromizer, Comet AG, Flamatt, Switzerland) [the Macromizer instrument is no longer commercially available.] The Macromizer instrument is designed to optimize ion transmission onto the small area of the cryodetector array. Every part of the instrument, including all necessary ion optics, laser, and electronics, were designed to enhance detection of high mass ions. For ionization, a $337 \mathrm{~nm}$ nitrogen laser (VSL 337ND-S, Spectra-Physics, Mountain View, CA), capable of producing energies up to $90 \mathrm{~mJ}$ with $4 \mathrm{~ns}$ pulse widths at $5 \mathrm{~Hz}$ repetition rate is focused to a spot size of $\sim 0.1 \mathrm{~mm}$. A detailed description of the Macromizer design is given by Wenzelíetíal.í[12].íForítheíworkídescribedíiníthisípaper, $15 \mathrm{kV}$ sample plate voltage, $3 \mathrm{kV}$ extraction voltage, 8 $\mathrm{kV}$ Einzel lens voltage, and $4 \mu$ s delayed extraction time were used. Spectra were acquired by averaging 200 to 250 shots and processed using the Data Analyzer software (Comet).

\section{MCP MALDI-TOF MS}

MALDI mass spectra using a microchannel plate (MCP) detector were obtained using an Ultraflex MALDI-TOF mass spectrometer (Bruker Daltonics, Bremen, Germany) equipped with a 337-nm nitrogen laser, a gridless ion source, delayed-extraction (DE), and a 2-GHz digitizer. The instrument was operated in linear mode by applying an acceleration voltage of $20 \mathrm{kV}$. The delay time used was 500 ns. Mass spectra were acquired by averaging 300 to 400 shots.

\section{Sample Preparation}

The matrix 2,6-dihydroxyacetophenone (Fluka Chemie, Buchs SG, Switzerland) was dissolved at a concentration of $10 \mathrm{mg} / \mathrm{mL}$ in $30 \% \mathrm{ACN} / 20 \mathrm{mM}$ ammonium citrate in water. Lyophilized venom from Sistrurus miliarius barbouri was purchased from Latoxan Serpentarium (Rosans, France). Lyophilized venom was dissolved in water and insoluble material was removed by centrifugation at 13,000 $\mathrm{g}$ for $10 \mathrm{~min}$ at room temperature. The sample was diluted to a desired concentration with water, mixed at a 1:1 vol/vol ratio with matrix solution and $0.5 \mu \mathrm{l}$ of this solution was applied onto the MALDIítargetíplateíwithítheídried-dropletímethodí[15].

\section{D SDS PAGE}

Protein composition of lyophilized venom from Sistrurus miliarius barbouri was analyzed by 2D-SDS-PAGE using an IPGphor instrument (Amersham Biosciences, Uppsala, Sweden). For the first dimension (IEF), 500 to $1000 \mu \mathrm{g}$ of total venom proteins (in $250 \mu \mathrm{l}$ of $8 \mathrm{M}$ urea, $4 \%$ CHAPS, and $0.5 \%$ IPG buffer) were loaded on a 13 $\mathrm{cm}$ IPG strip ( $\mathrm{pH}$ range 3 to 10) using the following focusing conditions: $30 \mathrm{~V}$ for $6 \mathrm{~h}, 60 \mathrm{~V}$ for $6 \mathrm{~h}, 500 \mathrm{~V}$ for $1 \mathrm{~h}, 1000 \mathrm{~V}$ for $1 \mathrm{~h}$, and $8000 \mathrm{~V}$ for $2 \mathrm{~h}$. Electrophoretic separation (second dimension) was done in a $16 \mathrm{~cm} 15 \%$ acrylamide gel. Coomassie brilliant blue (Amersham Biosciences, Uppsala, Sweden) was employed for protein staining.

\section{Reverse Phase HPLC}

For reverse-phase HPLC separations, 2 to $5 \mathrm{mg}$ of crude venom were dissolved in $100 \mu \mathrm{l}$ of $0.05 \%$ trifluoroacetic acid (TFA) and 5\% acetonitrile, and insoluble material was removed by centrifugation at $13,000 \mathrm{~g}$ for $10 \mathrm{~min}$ at room temperature. Proteins in the soluble material were separated using an ETTAN LC HPLC system (Amer- 
sham Biosciences, Uppsala, Sweden) and a Lichrosphere RP100 C18 column $(250 \times 4 \mathrm{~mm}, 5 \mu \mathrm{m}$ particle size) eluted at $1 \mathrm{~mL} / \mathrm{min}$ with a linear gradient of $0.1 \%$ TFA in water (Solution A) and acetonitrile (Solution B) (isocratically ( $5 \% \mathrm{~B}$ ) for $5 \mathrm{~min}$, followed by 5 to $15 \%$ for $20 \mathrm{~min}, 15$ to $45 \%$ B for $120 \mathrm{~min}$, and 4 to $70 \%$ B for 20 $\mathrm{min})$. Protein detection was at $215 \mathrm{~nm}$.

\section{Results and Discussion}

\section{Quantitative Profiling of the Snake Venom}

The increased sensitivity for detection of high mass ions using the cryodetection MALDI-TOF mass spectrometerí isí showní iní Figureí1a.í Theí spectrumí isí displayed divided into 5 to $35 \mathrm{kDa}$ and 35 to $110 \mathrm{kDa}$ ranges for easier visualization, although it was acquired in a single acquisition. It shows a mass-independent signal response, further validated when compared with the HPLCípeakíareasí(seeílateríoníandíFigureí2a,íb,ícíand Tableí2).íInícontrast,íwheníanalyzingítheísameísample with a conventional MCP detector the spectrum clearly displays a dramatic signal decrease with increasing mass. Furthermore, fewer ion signals are observed with the MCP detector, thus not representing the same complexity of the biological sample observed by cryodetectioní MS.í Figureí 1bí showsí oneí ofí theí bestí mass spectra that we could achieve to get a mass profiling including high mass peaks with the MCP detector from our Ultraflex MALDI-TOF instrument (see the Experimental section). All parameters were optimized and replicates were done on different days.

The crude venom of Sistrurus miliarius barbouri was fractionatedí byí reverse-phaseí HPLCí (Figureí 2a).í The characterization of the proteins present in each fractioníwasípreviouslyídoneíbyíJuarezíetíal.í[14],íusing SDS-PAGE, MALDI-TOF MS, Edman degradation (N-terminal sequencing), and tandem mass spectrometry in a quadrupole-linear ion trap instrument (data not shown). Isolated proteins could be unambiguously assigned to protein families present in the Swiss-Prot/Tr EMBLídatabaseí[14].íSomeírepresentativeíexamplesíare includedíiníTableí1.íSeparationíofítheíproteinícomponents of the crude venom extract by 2D gel revealed the presenceíofífouríorífiveímajoríproteiníspotsí(Figureí2b), and the presence of isoforms for the serine protease (proteiní2)í[14].

An additional feature of cryodetector MS is its capability to measure total kinetic energy, not just the arrival

\section{Cryodetection MALDI-TOF MS}
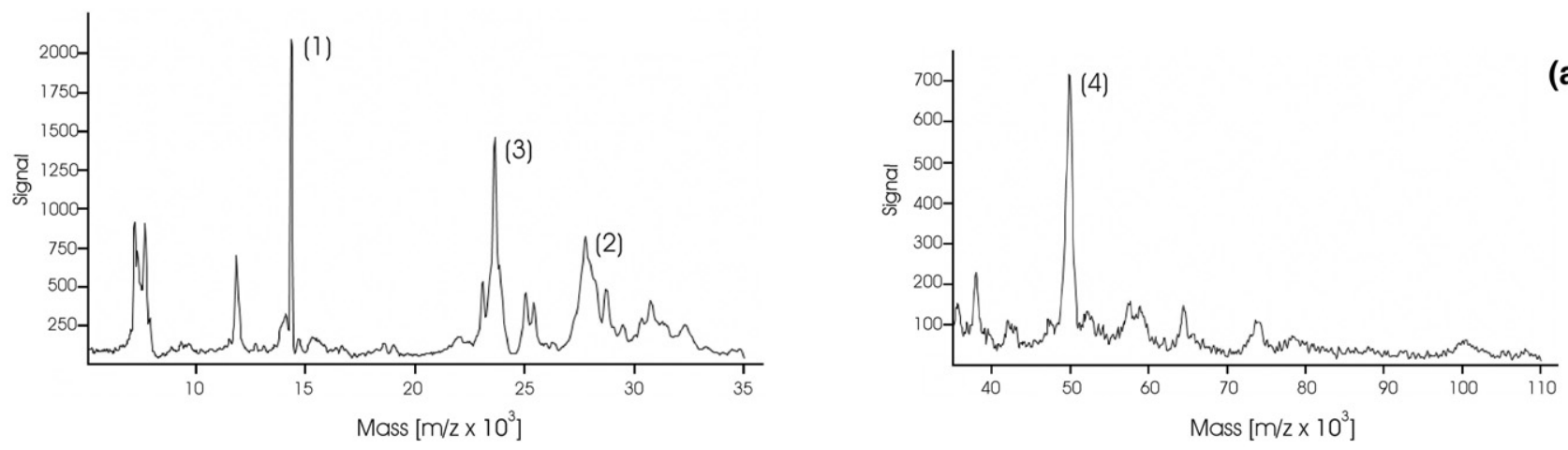

(a)

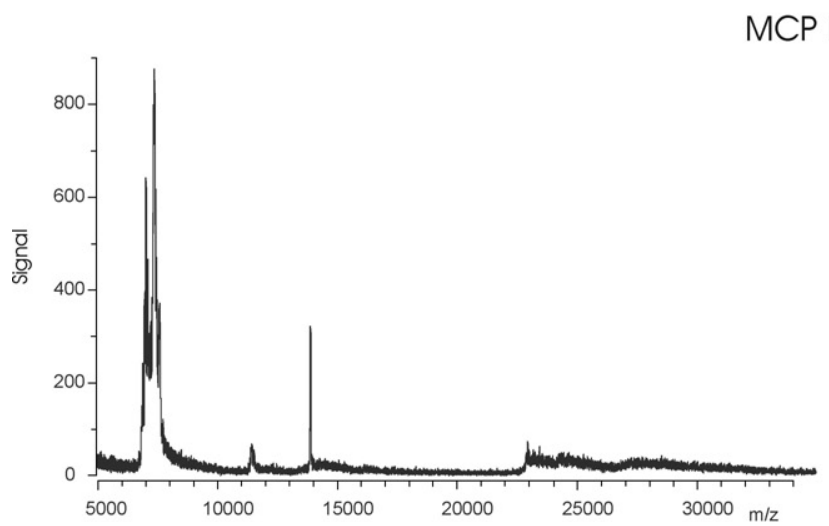

(b)

Figure 1. High-mass cryodetection (a) and microchannel plate (b) MALDI-TOF mass spectra of the S. miliarius barbouri venom extract. $0.8 \mu \mathrm{g}$ of total protein was deposited onto the MALDI plate without previousí fractionation.í Numbersí iní bracketsí indicateí proteinsí showní iní Tableí lí andí previously identifiedí[14]. 

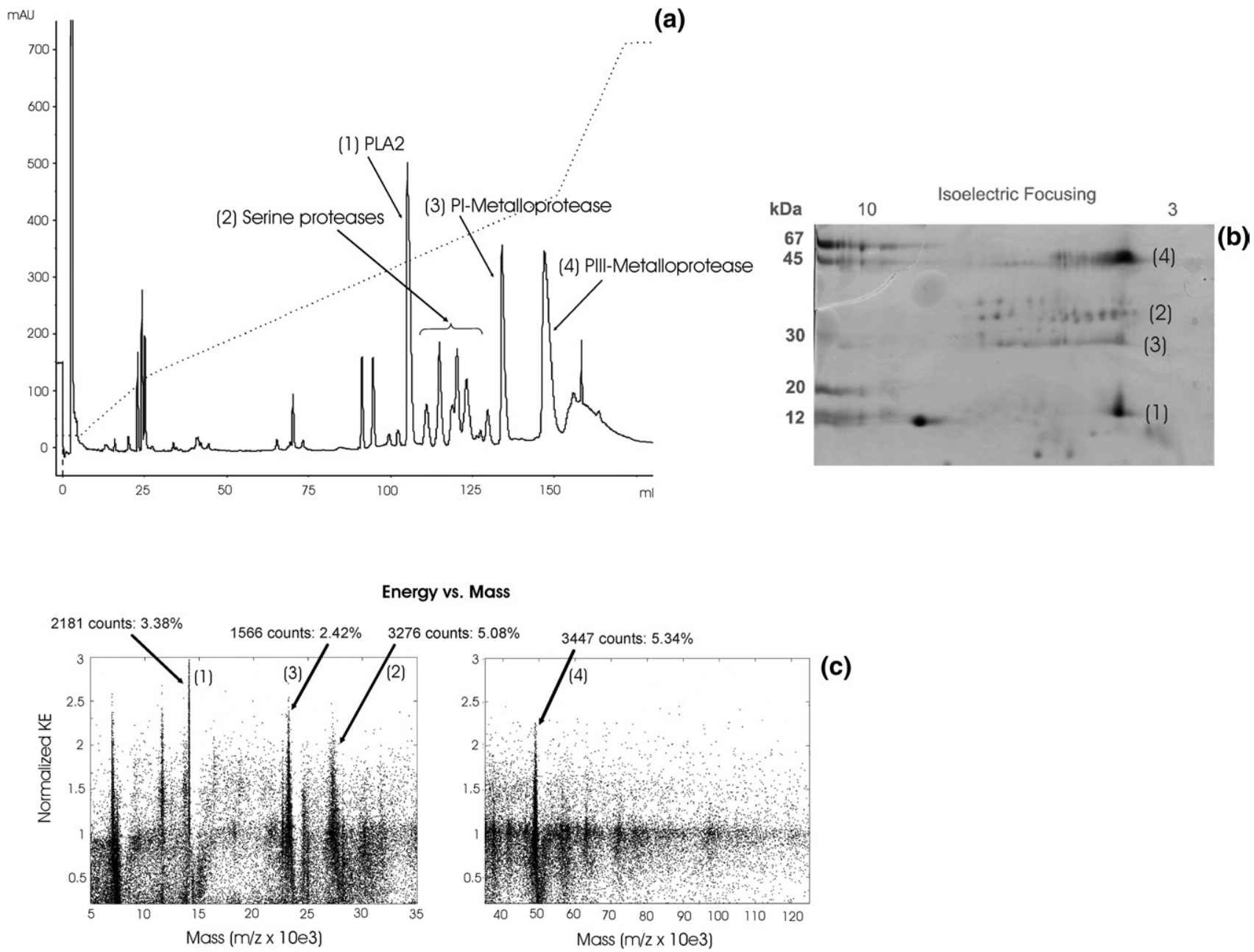

(c)

Figure 2. Separation of S. miliarius barbouri venom proteins by reverse-phase HPLC (a) and two-dimensional gel electrophoresis $(\mathbf{b})$. Total venom proteins $(1000 \mu \mathrm{g})$ were subjected to IEF using $13 \mathrm{~cm}$ IPG strip followed by SDS in a $15 \%$ acrylamide $(16 \mathrm{~cm})$. Scatterplot of individual ion events $\mathrm{m} / \mathrm{z}$ versus the normalized kinetic energy of each impact (c). Numbers in brackets indicate proteins shown iníTableílíandípreviouslyíidentifiedí[14].

time of the different ions. Energy is determined for each ion impact and is displayed as normalized kinetic energyí versusí $\mathrm{m} / \mathrm{z}$ ratio.í Figureí 2cí showsí theí energy versusím/z scatteríplotíofídataírepresentedíníFigureíla. The total number of ion counts in the 5 to $120 \mathrm{kDa}$ mass range was 64,459 . Ion counts for individual proteins of the extract and their respective percentage and relative valuesíwereíalsoícalculatedí(seeíTableí2).íAíkeyífinding is the excellent correlation between the chromato-
graphicírelativeípeakíareasí(Figureí2a),ífollowedíatí214 $\mathrm{nm}$, and the relative ion counts of each protein within theí cryodetectorí MSí (seeí Tableí 2).í Ultravioletí absorbance at $214 \mathrm{~nm}$ is widely recognized as a quantitative tool to determine the relative abundance of proteic components in a sample, with an accuracy of the same or superior level as gel electrophoresis with chromogenic staining. Although the latter, in the 2D mode, also correlates qualitatively, accurate quantitation of the

Table 1. Assignment of the reversed-phase isolated fractions of Sistrurus barbouri venom to protein families by N-terminal Edman sequencingíandíMALDI-TOFímassíspectrometryí([14])

\begin{tabular}{|c|c|c|c|}
\hline HPLC fraction & $\mathrm{N}$-terminal sequencing & $\begin{array}{c}\text { Isotope-averaged } \\
\text { MALDI-TOF mass }( \pm 0,2 \%)\end{array}$ & Protein family \\
\hline 1 & HLIQFETLIMKIAGRSGVFW & 13980 & Phospholipase A2 \\
\hline 2 & VIGGNECNINEHRSL & $27 \mathrm{kDa}^{\mathrm{a}}$ & Serine proteases \\
\hline 3 & NPEHQRYVELFIVVD & $23 \mathrm{kDa}^{\mathrm{a}}$ & PI-metalloprotease \\
\hline 4 & Blocked & $48.5 \mathrm{kDa}^{\mathrm{a}}$ & PIII-metalloprotease \\
\hline
\end{tabular}

${ }^{a}$ Apparent molecular mass determined by SDS-PAGE after sample reduction with $\beta$-mercaptoethanol. 
Table 2. Relative peak areas and ion counts values are the ratio of each protein value to the highest one (i.e., protein 4)

\begin{tabular}{|c|c|c|c|c|c|c|}
\hline \multirow[b]{2}{*}{ Protein } & \multicolumn{3}{|c|}{ HPLC } & \multicolumn{3}{|c|}{ Cryodetection MALDI-TOF MS } \\
\hline & Area $^{a}$ & Peak area $(\%)$ & $\begin{array}{l}\text { Relative } \\
\text { peak area }\end{array}$ & Ion counts ${ }^{b}$ & Ion counts $(\%)$ & $\begin{array}{l}\text { Relative } \\
\text { ion counts }\end{array}$ \\
\hline 1 & $6.019,618$ & 17.04 & 0.76 & 2181 & 3.38 & 0.63 \\
\hline 2 & $7.046,113$ & 19.95 & 0.89 & 3276 & 5.08 & 0.95 \\
\hline 3 & $3.911,487$ & 11.07 & 0.49 & 1566 & 2.42 & 0.45 \\
\hline 4 & $7.855,834$ & 22.23 & 1 & 3447 & 5.34 & 1 \\
\hline
\end{tabular}

aTotal area $(\mathrm{mAU} / \mathrm{ml}): 50.394,5$.

'Total ion counts: 64.459 .

spots is cumbersome and very dependent of the capability of the protein species to bind the chromogenic dye usedíforístainingí[16].íAsíexamples,ítheíproteiní4íofí48.5 $\mathrm{kDa}$ (PIII metalloprotease) seems to be the most abundant protein in our analysis, both in the mass spectrum andíRP-HPLCí(Figuresí1aíandí2a).íThisíproteinírepresents $5.3 \%$ of the total number of ions detected by cryodetector MALDI-TOF. Relative peak areas for proteins 1 and 3, PLA 2 (phospholipase $\mathrm{A}_{2}$ ) and PI- metalloproteinase from the RP-HPLC also fit quite well with the relative ion counts derived from the cryodetector MS data (seeí Tableí 2).í Forí proteiní 2í (serineí protease),í different isoforms appear in adjacent chromatographic peaks as previouslyídescribedí[14],íandítheípeakíareasíhaveíbeen integrated as one value that also fits very well with the ion countsíofítheícryodetectoríMSí(seeíTableí2).

One of the main disadvantage of cryodetection MALDI-TOF is its relatively low-resolution for the present mass spectrometric instrument. This is mainly dueítoítheíSTJ,íwhichíisíaníinherentlyíslowídetectorí[12], together with the fact that Macromizer is a linear TOF instrument (equipped with a $1.5 \mathrm{~m}$ drift region), and the delay pulse extraction over a wide mass range is generally problematic or impossible. These issues, for the time being, may prevent the detection of isoenzymes with very similar molecular mass until such technical constraints are solved. This is the case of the different isoforms of a serine-protease (protein 2 in this work)í previouslyí identifiedí byí Juarezí etí al.í [14]. Whereas the 2D-gel and the RP-HPLC show spots with different $\mathrm{pI}$ and the very similar MW and adjacent peaks in the RP-HPLC chromatogram, respectively (see Figureí 2a,íb),í theí heterogeneityí ofí isoformsí (peakí at $\sim 27.4 \mathrm{kDa}$ ) cannot be resolved as individual species from the cryodetection MALDI-TOF mass spectrum of Figureí 1aí andí theí energyí versusí $\mathrm{m} / \mathrm{z}$ scatterí plotí of Figureí 2c.í Oní theí otherí hand,í theí highí massí ion complexity (50 to $120 \mathrm{kDa}$ ) observed with the cryodetection MALDI-TOF could neither be detected with RP-HPLC nor with the 2D gel electrophoresis. In the case of the RP-HPLC, it would be explained because the characteristic reversible adsorption/desorption of analytes (by adjusting the polarity of the mobile phase) on the reversed-phase chromatography becomes sometimes irreversible with high mass proteins $(>50 \mathrm{kDa})$ due to their high hydrophobicity (specially using C18 and C8 ligands).

\section{Sensitivity of High-Mass Cryodetection MALDI-TOF MS}

High sensitivity is a crucial aspect of proteomics research. To date, the available stains for visualizing proteins in a 2D gel yield relatively poor sensitivity or poor peptide recovery for mass spectrometric investigation of in-gel digests. In addition, the limited dynamic range of these stains has made it difficult to rigorously and reliably determine differences in protein quantitiesí (especiallyí forí silverí staining).í Figureí 3 shows the energy versus $\mathrm{m} / \mathrm{z}$ scatter plot of the snake venom extract at decreasing amounts of total protein. While the detection limit for a single protein using (MS compatible)í silverí stainingí liesí atí aroundí 40í ngí [17], cryodetection MS seems to be at least 10 times more sensitive. Previous cryodetector research showed sensitivities as low as 1 femtomole for a single protein sampleí ofí aní antibodyí [18].í Limitsí ofí detectioní were defined as the lowest concentration points for which signals were still reproducibly detected with a signalto-noiseíratioí $\geq 2$.íFigureí3íshowsíhowítheítotalínumber of ion counts is decreasing to the amount of total protein deposited onto the MALDI plaque, but the ion count percentage of single proteins is maintained independentlyí ofí theirí massí (seeí Tableí 3).í Onlyí aí few proteins above $60 \mathrm{kDa}$ could not be detected at very low concentrations of total protein. The detection limit for a feasible relative quantification of different proteins in this sample with the Macromizer instrument was established as $10 \mathrm{ng}$ of total protein. It is worth mentioning that there is under advanced development a new generation of related high mass MALDI-TOF detector, the ICD, which does not require the cryostat and shows a very similar sensitivity (and signal uniformity) along a broad mass range with protein samples similar to the onesíhereíanalyzedí[13].

\section{Conclusions}

In the present study, two completely different MALDI-TOF mass spectrometers were used to com- 

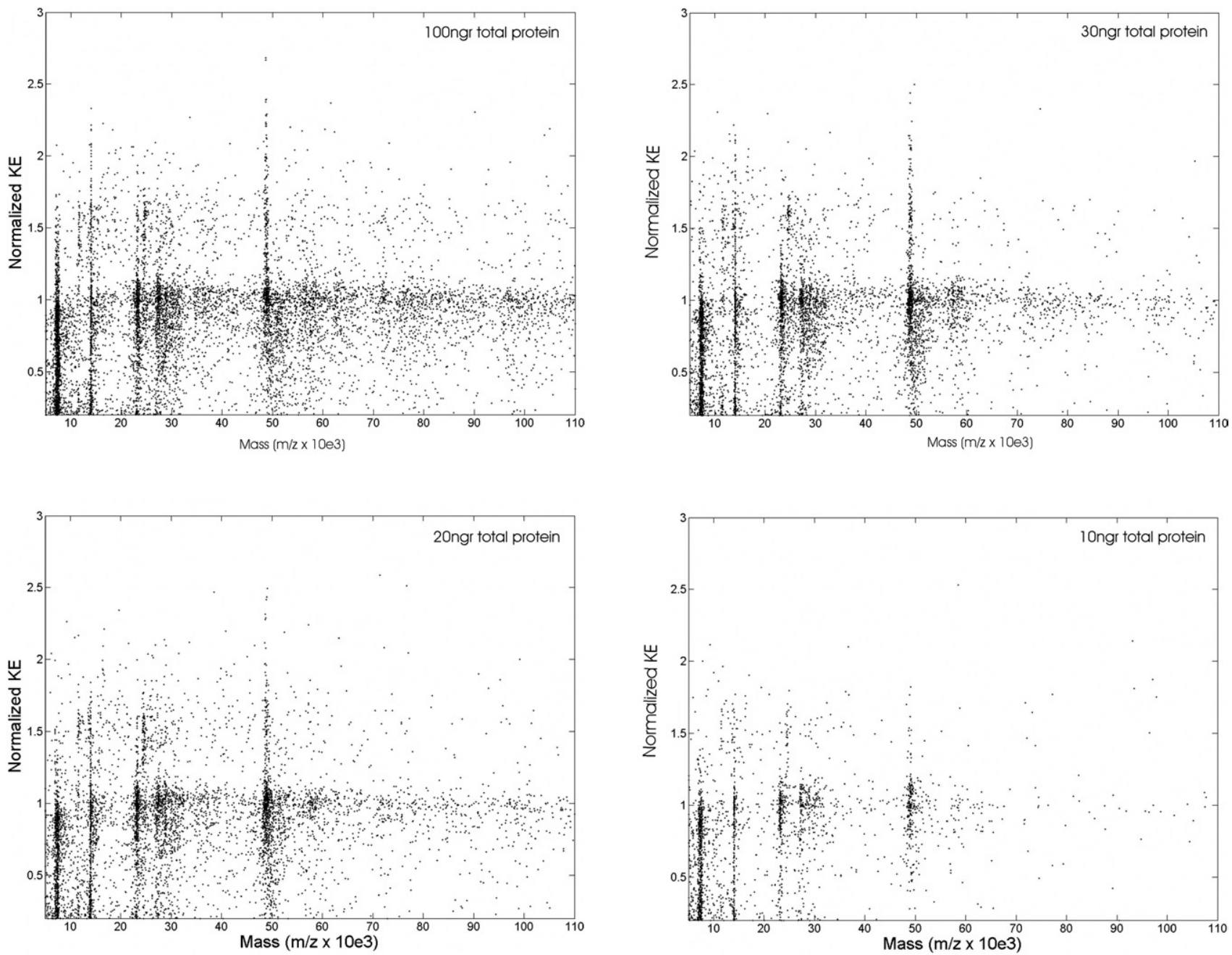

Figure 3. Scatter plot of individual ion events in the high-mass cryodetector, $m / z$ versus the kinetic energy of each impact; $100,30,20$, and $10 \mathrm{ng}$ of total venom proteins were deposited onto the MALDI plaque.

pare their performance exploring the mass profiling of a snake venom extract, fitted with two different detectors, either the currently used MCP or a highmass cryodetector. Although the main difference concerns their detectors, other $m / z$ biases in the instruments (e.g., different ion transmissions) cannot be disregarded.
The snake venom extract is not an extremely complex biological sample, so we have taken advantage of the mass-independent protein detection and very high sensitivity of cryodetection MS to obtain one of the most complete mass profiling to date of this biological (crude) extract without any previous fractionation step. Obviously, we cannot assert that it is the true sample

Table 3. Ion count percentage of single proteins at decreasing amounts of total protein

\begin{tabular}{|c|c|c|c|c|c|c|}
\hline \multirow[b]{2}{*}{ Total protein (ngr.) } & \multirow[b]{2}{*}{ Total counts } & \multicolumn{5}{|c|}{$\begin{array}{l}\text { Percentage of individual proteins from total protein by ion signal } \\
\text { at specific mass ranges }(\mathrm{kDa})\end{array}$} \\
\hline & & $7-8$ & $11.5-12.2$ & 14-15 & $23-24$ & $49-51$ \\
\hline 100 & 9895 & 12.79 & 1.26 & 6.08 & 5.50 & 6.44 \\
\hline 30 & 6355 & 13.13 & 1.74 & 7.94 & 6.89 & 10.63 \\
\hline 20 & 6638 & 10.03 & 1.79 & 8.24 & 6.83 & 10.36 \\
\hline 10 & 2475 & 22.26 & 2.02 & 10.10 & 7.11 & 8.48 \\
\hline Average & & 14.55 & 1.70 & 8.09 & 6.58 & 8.98 \\
\hline Std. dev. & & 5.32 & 0.31 & 1.64 & 0.72 & 1.94 \\
\hline Coef. variation & & 36.55 & 18.65 & 20.31 & 11.07 & 21.62 \\
\hline
\end{tabular}


complexity as there may be protein species present in the sample that are at levels too low to be visualized. However, if this is the case, neither 2D-gel electrophoresis nor HPLC data seem to detect them.

Theoreticalí andí practicalí considerationsí [12],í and assuming absence of bias in ion transmission, lead to the conclusion that STJ ion counts, displayed as normalized kinetic energy versus $\mathrm{m} / \mathrm{z}$ ratio, represents the closest true ion yield of the MALDI process. This shows the potential of cryodetection MALDI-TOF MS (or equivalent next generation high mass detectors) as a promising tool for mass spectrometry-based quantitative proteomic profiling strategies. Considering that in such instruments signal suppression effects due to the detector are absent, quantification of the protein content using MALDI mass spectrometry will only depend on the relative ionization efficiencies of the different compounds within a complex mixture, again assuming absence of bias in ion transmission. For this reason, complementary previous fractionation and separation procedures should be performed in future proteomic strategies to increase the ionization efficiency of as many proteins as possible.

Although over the last several years there have been many advances for mass spectrometry in ionization methods, mass separation, and fundamental understanding, one of the most important steps in this process, the detection of ions, has remained virtually unchanged. The present study demonstrates that novel detection technologies, exemplified by high-mass cryodetection, may open up new strategies and applications for mass spectrometry in high-throughput proteomic projects.

\section{Acknowledgments}

This work was supported by grant no 200020-103616 (Swiss National Science Foundation), grants GEN2003-20642-C09-05, and BIO2004-05879 (Ministerio de Ciencia y Tecnologia, MCYT, Spain), and by Centre de Referència en Biotecnologia (Generalitat de Catalunya, Spain). OY acknowledges a fellowship from MCYT.

\section{References}

1. Villanueva, J.; Philip, J.; Entenberg, D.; Chaparro, C. A.; Tanwar, M. K.; Holland, E. C.; Tempst, P. Serum Peptide Profiling by Magnetic Particle-Assisted, Automated Sample Processing and MALDI-TOF Mass Spectrometry. Anal. Chem. 2004, 76, 1560-1570.

2. Caldwell, R. L.; Caprioli, R. M. Tissue Profiling by Mass Spectrometry: A Review of Methodology and Applications. Mol. Cell. Proteom. 2005, 4 , 394-401.

3. Issaq, H. J.; Veenstra, T. D.; Conrads, T. P.; Felschow, D. The SELDI-TOF MS Approach to Proteomics: Protein Profiling and Biomarker Identification. Biochem. Biophys. Res. Commun. 2002, 292, 587-592.

4. Kelleher, N. L. Top Down Proteomics. Anal. Chem. 2004, 76, 197A-203A.

5. Sheng, S.; Chen, D.; Van Eyk, J. E. Multidimensional Liquid Chromatography Separation of Intact Proteins by Chromatographic Focusing and Reversed Phased of the Human Serum Proteome: Optimization and Protein Database. Mol. Cell. Proteom. 2006, 5, 26-34.

6. Zhang, N.; Li, N.; Li, L. Liquid Chromatography MALDI MS/MS for Membrane Proteome Analysis. J. Proteome Res. 2004, 3, 719-727.

7. Twerenbold, D.; Gerber, D.; Gritti, D.; Gonin, Y.; Netuschill, A.; Rossel, F.; Schenker, D.; Vuilleumier, J. L. Single Molecule Detector for Mass Spectrometry with Mass Independent Detection Efficiency. Proteomics 2001, 1, 66-69.

8. Brunelle, A.; Chaurand, P.; DellaNegra, S.; LeBeyec, Y.; Parilis, E. Secondary Electron Emission Yields from a CsI Surface Under Impacts of Large Molecules at Low Velocities [5x10(3)-7×10(4) ms(-1)]. Rapid Commun. Mass Spectrom. 1997, 11, 353-362.

9. Chen, X. Y.; Westphall, M. S.; Smith, L. M. Mass Spectrometric Analysis of DNA Mixtures: Instrumental Effects Responsible for Decreased Sensitivity with Increasing Mass. Anal. Chem. 2003, 75, 5944-5952.

10. Frank, M.; Mears, C. A.; Labov, S. E.; Benner, W. H.; Horn, D.; Jaklevic, J. M.; Barfknecht, A. T. High-Efficiency Detection of 66,000 Da Protein Molecules Using a Cryogenic Detector in a Matrix-Assisted Laser Desorption/Ionization Time-of-Flight Mass Spectrometer. Rapid Commun. Mass Spectrom. 1996, 10, 1946-1950.

11. Twerenbold, D. Cryogenic Particle Detectors. Rep. Prog. Phys. 1996, 59, $349-426$.

12. Wenzel, R. J.; Matter, U.; Schultheis, L.; Zenobi, R. Analysis of Megadalton Ions Using Cryodetection MALDI Time-of-Flight Mass Spectrometry. Anal. Chem. 2005, 77, 4329-4337.

13. Wenzel, R. J.; Nazabal, A.; Zenobi, R. Comparison of Sensitivity and Saturation of MALDI-TOF Detectors for High-Mass Ions. Proceedings of the 54th ASMS Conference on Mass Spectrometry; Seattle, May 2006.

14. Juarez, P.; Sanz, L.; Calvete, J. J. Snake Venomics: Characterization of Protein Families in Sistrurus barbouri Venom by Cysteine Mapping, N-terminal Sequencing, and Tandem Mass Spectrometry Analysis. Proteomics 2004, 4, 327-338.

15. Hillenkamp, F.; Karas, M. Laser Desorption Ionization of Proteins with Molecular Masses Exceeding 10,000 Daltons. Anal. Chem. 1988, 60, 2299-2301.

16. Rabilloud, T. Two-Dimensional Gel Electrophoresis in Proteomics: Old, Old Fashioned, but It Still Climbs Up the Mountains. Proteomics 2002, 2, 3-10.

17. Rabilloud, T. Detecting Proteins Separated by 2D Gel Electrophoresis. Anal. Chem. 2000, 1, 48A-55A.

18. Chaurand, P.; Hayn, G.; Matter, U.; Caprioli, R. M. Proceedings of the 52nd ASMS Conference on Mass Spectrometry and Allied Topics; May 2004, Nashville, TN. 